\title{
Fact Finding Visit to Central America
}

Excerpts from the Dawson Report*

The refugee situation in Central America involves upwards of half a million people. More than $10 \%$ of the entire population of El Saliador is either in internal or external exile... there are definite prospects that there will be an increase in the number of refugees in the area. UNHCR policy is accepted by and large by most countries in the region which at least tolerate the presence of Salvadorans and Guatemalans on their territory.

Canada's primary role will continue to be that of a donor of aid and as a catalyst for effective UNHCR programs in the area. Immigration, therefore, must complement CIDA programs of humanitarian relief and initiatives by External Affairs directly with the UNHCR or through the Executive Committee.

Canadian policy in regard to providing resettlement as a means of protection for those who suffer hardship in countries of first asylum or who are in danger of being returned to the countries from which they have escaped has been well received. It will not generate a significant flow of refugees to be resettled in Canada from within Central America itself but needs to be continued as an indispensable complement to UNHCR policy.

Awareness of our policy varied considerably throughout the region. We had made the greatest impact in Mexico City, Dallas and San Jose, Costa Rica, where the combination of a strong Canadian presence and visits by Canadian Church representatives served to publicize and reinforce information regarding Canadian refugee policy. Offices in the region need to continue to build referral networks so that potential recipients of resettlement facilities can be identified.

Central America will likely grow in importance as a source of refugees to be resettled in Canada. Our coverage in the area... does not seem appropriate to a region where we are attempting to implement a highly sensitive refugee program responding to individual needs. More attention needs to be paid to reporting and intelligence gathering on refugee matters, particularly in those countries where we do not have full-time representatives.

The team noted that immigration officers working in the area had a preference to fit cases with obvious humanitarian interest for Canada into the March 1981 special program rather than deal with them under the Latin American refugee program.

The profile describing those Salvadoran refugees that we are interested in assisting is valid but may be too restrictive to fully achieve policy objectives. Several sources reported that in addition to those persons involved in promoting measures for social progress or delivering services in El Salvador, those persons of military service age, both male and female with secondary or post-secondary education, would be in jeopardy if forced to return to El Salvador. Those in the foregoing category from guerilla controlled areas would most certainly face persecution if returned to their own country.

The Canadian program has potential for significant growth in proportion to the success or failure of groups in the United States in using litigation as a means of obtaining de facto protection for Salvadorans in the U.S.A. This momentum is unlikely to produce a great deal in terms of refugee intake in 1982, but may be significant in 1983 and beyond.

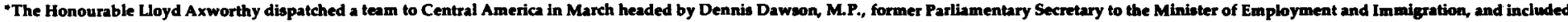

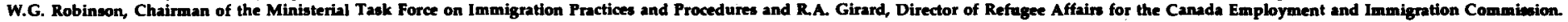

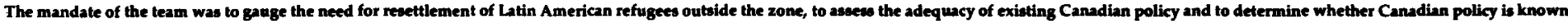
and applied in the region in an effective way.

\section{Canadian Resettlement Policy}

Canada has a useful role to play through resettlement in Canada of those refugees who cannot be protected in countries of first asylum or those who are in imminent danger of being returned to the country from which they have fled.

\section{Canadian Financial Aid}

Canada has provided $\$ 750,000$ in financial and material aid in response to various appeals from international agencies active in the area.

\section{The Role of the UNHCR}

It is UNHCR'S intention to protect and assist Central American refugees within the region insofar as possible until a political solution is achieved thereby facilitating orderly repatriation or local resettlement, whichever is dictated by the outcome. For example, there are approximately 400 Salvadoran refugees in Panama who, after considerable effort by UNHCR field staff were permitted to settle on the land.

\section{Resettlement Policy Abroad}

Several hundred Salvadorans have been accepted in Mexico City as Convention refugees or under relaxed criteria. In addition, Sal- vadoran applicants abroad with close relatives in Canada are being processed under relaxed selection criteria.

\section{Resettlement Policy in Canada}

Earlier in 1981, Salvadorans already temporarily in Canada were granted de facto protection through suspension of deportation, except in cases of national security, and change of status privileges which were made available to those who had relatives or who could prove they had the ability to resettle in Canada. Adjustment of status privileges in Canada has benefitted more than 400 Salvadorans. 